\title{
A Philosophical Approach Towards the Concept of Freedom in Henry James's The Portrait of a Lady
}

\author{
Mahdi Shamsi \\ Department of English, The Rutherford College, University of Kent, Canterbury, Kent CT2 7NX, UK \\ Department of Philosophy, Faculty of Arts, Gent University, Blandijnberg 2, B-9000, Ghent, Belgium \\ E-mail: ms596@kent.ac.uk
}

Received: 25-03- 2015

Published: 01-11- 2015
Accepted: 22-06- 2015

doi:10.7575/aiac.ijalel.v.4n.6p.64
Advance Access Published: August 2015

URL: http://dx.doi.org/10.7575/aiac.ijalel.v.4n.6p.64

\begin{abstract}
Freedom is one of the major elements in Henry James's The Portrait of a Lady. In an age when American women were usually engaged or married, James's heroine, Isabel, was somewhat ahead of her time in hoping for a marriage in which she could still be independent. She was very fond of her liberty and afraid of losing it, but does her return to her husband, Osmond, at the end of the novel suggest that she has put an end to her eagerness for freedom? It is an underlying argument of this study that James's novel, in its last scene, covers a different aspect of freedom which, through a Schopenhauerian approach, delivers a different insight into liberty. This perception of freedom in The Portrait of a Lady has never been considered in connection with Arthur Schopenhauer's view on the experience of freedom. The implicit critical point on which the paper is founded is that, although Schopenhauer is not conspicuously mentioned in James's notes, there is important evidence that shows the convergence between the thoughts of Schopenhauer and Henry James; that is, that evidence through which this study aims to analyse the heroine's final decision in the last scene.
\end{abstract}

Keywords: independence, marriage, resignation, philosophy of positive and negative freedom

\section{Introduction}

One of the technical points James considered in the writing of The Portrait of a Lady was, on the one hand, to keep the reader alert to Isabel's individuality and, on the other hand, to persuade the reader that she could achieve a sense of morality through recognition of her own character. This picture attracts the readers' thoughts to the absurdity of the heroine's claim of superiority. A woman who announces her freedom would finally be entangled in a form of confinement. More ambiguity arises when the heroine (Isable) with all the problems in her relationship with her husband aims to return to him while she receives a new proposal that offers her a life of passion and freedom. By considering Schopenhauer's philosophy of freedom, this study aims to form a complex and dynamic interpretation of James's idea of liberty in The Portrait of a Lady. Indeed, it is an underlying argument of this study that James's novel, in its last scene, covers a different aspect of liberty which, through a Schopenhauerian approach, delivers a different insight into freedom.

Isabel's negative will to do everything she wants is significant from the first scene: she moves to England and when told that, in England, young girls do not sit with gentlemen alone late at night, she argues that "I always want to know the things one shouldn't do" (Portrait, p. 68). James represents Isabel as a young American woman that does not like to sacrifice her freedom, clings to American culture and has strong desires. "Expectation is, in fact, the structural principle on which The Portrait of a Lady is built. In order to make the question 'what will she do?' significant, James frees Isabel from all external inhibitions" (Wegelin, 1958, p. 66). He portrays a woman who is immature and has illogical desires. From the start of the novel, Isabel is shown to be liberty-loving but naive in her expectation that she can get away with that. She does whatever she pleases and her life is built upon her expectations and desires. In the early chapters, Isabel is an independent woman, refusing all her suitors in order to save her freedom but later she chooses Osmond in hope that her marriage to him will guarantee her liberty. Her reasoning faculty works in parallel to her will and leads to her conjugal tie with Osmond. It is after the marriage that Isabel's character is given by the narrator a "higher degree" (Portrait, p. 416), to enable her to see the whole instead of the particular. Being away from independence and free will, Isabel's faculty of reason finds a chance to observe the world in a more realistic way; she "judge[s] herself" and she "see[s] the reality" (Portrait, p. 557). James's novel seems elaborately designed to contend that liberty in marriage is a problem in such a modern world. Before marriage, Isabel's "notion of the aristocratic life was simply the union of great knowledge with great liberty" (Portrait, p. 431) but later she realises that "marriage meant that a woman should cleave to the man" (Portrait, p. 540) with whom she has to choose what he chooses. It is almost as if James considered this problem to show how Isabel, a thoughtless and self-centred woman who did not have real knowledge of the world, could blossom into a noble woman by experiencing the reality of life through her marriage to Osmond. 


\section{Traces of Schopenhauer}

Thomas Sergeant Perry writes in his diary about a day that he spent with his friend Henry James and the two other James brothers in Newport where William read extracts from Schopenhauer's The World as Will and Idea on a family vacation in 1858. Perry wrote of their days together and of how they first heard of Schopenhauer from the oldest brother:

We fished in various waters, and I well remember when William James brought home a volume of Schopenhauer and showed us with delight the ugly mug of the philosopher and read us amusing specimens of his delightful pessimism. (Matthiessen, 2007, p. 89)

It was William who first told Henry about Schopenhauer. Furthermore, a partial bibliography of James's library, The Library of Henry James, which was compiled by Adeline Tintner and Leon Edel lists Schopenhauer's Essays (1899) as having been owned by James. This book is among those whose whereabouts are unknown but whose titles have been derived from the three Fabes catalogues and the Hodgson list. ${ }^{i}$

The other documented evidence which points to James's understanding of Schopenhauer is The Princess Casamassima (1886). This novel alludes to Schopenhauer many times. The novel gives "his readers a hint that the philosophy of Schopenhauer was not far from his mind as he wrote The Princess Casamassima, and granted a kind of permission to read the book as an objectification of many Schopenhauerian ideas" (Firebaugh, 1958, p. 178). Firebaugh argues that James's novel is strongly indebted to Schopenhauer's misogyny, the concepts of art, the will to live, and the theory of life as an alternation of boredom and happiness. It would appear that James was likely in accord with the concepts of Schopenhauer, viewing them as a possibility for the advancement of artistic skills. James may have read a little about Schopenhauer in his teenage years but from the repeated use of his name in The Princess Casamassima, it seems that he would have been interested in the high currency of Schopenhauer's name in the 1880s.

J. Firebaugh's article "A Schopenhauerian Novel: James's The Princess Casamassima" appears to be the only study that has indicated the importance of Schopenhauer to James. Firebaugh has drawn some links between James and Schopenhauer and he believes that in writing The Princess Casamassima, James thought of certain aspects of Schopenhauer's philosophy, such as misogyny, the pendulum swing of life between satiation and ennui, and the will to live. ii Where this study's approach differs from Firebaugh's is in its technical concentration on Schopenhauer's philosophy of freedom in order to form a complex and dynamic interpretation of James's idea of liberty in The Portrait of a Lady.

\section{Experience of Negative and Positive Freedom}

For Schopenhauer, aesthetic experience has an ethical importance. He considers two sorts of experiences: first, the experience of negative freedom and secondly, the experience of positive freedom. In negative freedom, the individual is in the service of the will, while in positive freedom, he frees himself from the servitude of the will. In positive freedom, the individual recognises the object in a non-egoistic manner. In fact, the self-consciousness gained from experience enables the person to change his behaviour and attitudes from a wilful state to a will-less state. In Schopenhauer's philosophy, rejection of the will is accomplished in two ways: either through a personal experience of an extreme suffering that leads to loss of the will or through recognition of the essential nature of life, the will. Schopenhauer's principle is predicated on embracing a benevolent attitude for others while striving with a sharpened awareness of what would be in their best interest. This attitude is the initial element in the understanding of compassion. The most offensive part of Isabel's character arises from her egotistical quality, erroneous image of independency and her inability to overcome the self. "You could have made her colour, any day in the year, by calling her a rank egoist. She was always planning out her development, desiring her perfection, observing her progress" (Portrait, p. 53). The ideal of freedom is motivated by Isabel's selfishness and "wilful" characteristic (Portrait, p. 345). These two characteristics subordinate her imagination towards a deluded picture of freedom. But her ethical life forms through the same portrait; Isabel becomes conscious regarding the existence of the will behind her actions through her suffering in her miserable marriage. This realisation subsequently empowers her to ignore herself. Indeed, James presents a psychologically realistic character whose behaviour is a direct outgrowth of her self-satisfaction, with her clashes resulting from the differences between her expectations and the reality of her surrounding environment.

There are a number of connections that Schopenhauer sketches between the positive experience of freedom and his ethic of compassion. He claims that "true loss is just as impossible as true gain in this world of appearance. Only the will exists: it, the thing in itself, is the source of all those appearances. Its self-knowledge and its consequent decision to affirm or to negate is the only event in itself" (World 1, p. 207). If we take this passage into consideration, then we realise that Isabel's final circumstance is to affirm or negate her will. Since her experience is the only way to attain an accurate understanding of the world in all its multiplicity, it seems that experience and suffering are the essential preconditions for making her ethical choice (refusing Goodwood's offer). Therefore, this particular consciousness gained by experience will prove to be of a moral significance in the novel. Indeed, James presents a psychologically realistic character whose behaviour is a direct outgrowth of her self-satisfaction, with her clashes resulting from the differences between her expectations and the reality of her surrounding environment.

James delineates this significant cognition of experience and freedom by presenting an unexperienced woman who is looking for liberty. He ends the novel by leaving the heroine between two options of freedom. It is in his conclusion, when Goodwood's seductive words beseech Isabel not to return to her husband, that James releases the main point of his moral art. Goodwood hopes that Isabel would once more be persuaded by her longing for freedom and 
independence. Here, going back to Osmond must be a genuine option for Isabel, otherwise the choice of staying with Goodwood can only be another imprisonment. Indeed, the last affairs that Goodwood passionately embraces and kisses Isabel represents that "sexual fulfilment may depend on a complete relinquishing of a person's freedom and independence" (Buelens, 2005, p. 5). James leaves the heroine free to choose between staying with Goodwood or returning to Osmond. Nonetheless, with regard to her previous experience (no liberty in marriage with Osmond), she does manage to free herself from the servitude of the will, a positive freedom. Clearly, there are actual pictures of freedom in her mind, but at that specific moment she is not the unexperienced woman of the early chapters. In the light of self-consciousness, she comes to the felt recognition that she has the power to act in a less egoistic manner. Consequently, if the unconscious side of Isabel dominates, and she pursues her desire for a personal independence, then accepting Goodwood's proposal will deliberately put her in another imprisonment, which represents her pursuit for negative freedom. ${ }^{\text {iii }}$ But if the conscious side of her is to dominate, then we can consider her returning to Osmond as a positive freedom which suggests her moral consistency.

\section{Freedom and Possession}

The truth of marital possession is exhaustively explored in James's novel. As showed previously, this idea is sophisticatedly depicted in Isabel's character development throughout the novel, not only in her relationship with Osmond but also with other lovers. Schopenhauer in his essay on "Metaphysics of Love" pays great attention to the matter of possession in marriage. It appears that The Portrait of a Lady articulates such a view as well, the truth that marriage is in opposition to individual independence.

Schopenhauer believes that "the fundamental fault in the character of women is that they have no "sense of justice." This arises from their "deficiency in the power of reasoning" (Women, p. 44). Regarding the limited reasoning power in women, he continues that

Woman is by nature intended to obey is shown by the fact that every woman who is placed in the unnatural position of absolute independence at once attaches herself to some kind of man, by whom she is controlled and governed; this is because she requires a master. If she, is young, the man is a lover; if she is old, a priest. (Women, p. 51)

Schopenhauer had an unambiguous hatred and fear of women. ${ }^{\text {iv }}$ As Thomas Grimwood states in "The Limits of Misogyny: Schopenhauer, 'On Women'” (2008), "such 'information' is often purely hypothetical and speculative, rarely based on any substantial empirical evidence" (p. 134). " But the above quality in some degree applies to Isabel's attitudes. She always returns to her theory that a woman "ought to be able to live to herself, in the absence of exceptional flimsiness, and that it was perfectly possible to be happy without the society of a more or less coarseminded person of another sex" (Portrait, p. 53). It is this idea that comforts her in "being independent" (Portrait, p. 52). But after receiving the opportunity for independence through the fortune of her heritage, she continues pursuing her ideal mate. Although Isabel insists on retaining her independence, she is simultaneously drawn towards her inescapable destiny, marriage. Thus, her unique desire for freedom turns out to produce possession in marriage.

Osmond is descended from a pretentious mother who wished to be known as the American Corinne. He appears delightfully negative and unconditional; as Madam Merle points out he has "No career, no name, no position, no fortune, no past, no future, no anything" (Portrait, p. 197). Even with all she knew about him, she ushers Isabel towards marrying him. Osmond, with Merle's assistance, encourages Isabel's desires, in order to overcome other suitors, because her money is his main motivation behind this marriage. On the other side, one of the things that motivate Isabel is her unquenchable desire to be pleased. In the narrator's words, "she married to please herself. One did other things to please other people; one did this for a more personal satisfaction" (Portrait, p. 349). Shortly after their marriage, Osmond's interest in his wife becomes a kind of possession and dominance. He sees her exclusively as an acquisition to be controlled and he wants to stifle her freedom. Hereafter, The Portrait of a Lady forms a notable contribution to the discussion of domination by an alternative view of mastery, as well as slavery. It is worth recalling Gert Buelens's description of the final scene when Goodwood kisses Isabel, "the imagery of the scene is sensuous, yet it also clearly brings out the bound and unfree condition that giving in to such sensuality involves, a condition that is like being drowned, exposed to lightning and submitted to possession" (p. 5). Indeed, Isabel has to "allow herself to be thus possessed by a man" (Buelens, 2005, p. 4-5). Osmond's exploitive manner in marriage shows that by profitably possessing Isabel, then restricting her into his own views rather than leaving her free to go after her desires, she is imprisoned by him instead of gaining more freedom. One of the significant elements of the novel is Osmond's authoritarianism; his authoritarianism urges Isabel not to go to England to see her cousin and also obliges his daughter, Pansy, to marry Warburton because of money. In fact, Osmond's egoistic love of authority disassembles Isabel in what Ralph names "the very mill of the conventional" (Portrait, p. 577).

Further, Osmond admires Isabel's mind but only when her thinking reflects back his opinions. This arises from his sense of possession and superiority. His ignorance of her separate identity, or mind, resembles Schopenhauer's belief that women lack objectivity of mind and that is why "they always stick to what is subjective" (Women, p. 47). ${ }^{\text {vi }}$ Accordingly, he claims that a woman's sense of fairness is weaker than a man's because "their attention [is] fixed upon what lies nearest" (Women, p. 44). Schopenhauer compares a woman in this respect to "an organism that has a liver but no gall-bladder" (Women, p. 44). Osmond's manner easily presents this idea because he refuses Isabel's mind, and yet, he is still slightly entertained by her imagination. He considers her mind as a small garden lying within the vast garden 
of his mind, although the narrator claims that Isabel has a sharp "mind of her own" (Portrait, p. 432). In these conflicting layers, the reader should bear in mind that owning a sharp mind in Isabel is the quality that makes her "a prodigy of learning" (Portrait, p. 49) while in another scene the narrator emphasises that she thinks that she knows "a great deal of [everything]" (Portrait, p. 43), but indeed she is unaware that there are many matters of which she has no knowledge. More contracting information surfaces when James provides an access to Isabel's memories of the first few years of her life with Osmond. We discover that she has "lived with [Osmond's mind], she [has] lived in it almost - it appear[s] to have become her habitation" (Portrait, p. 428). By conflating Isabel's thoughts and theories with Osmond's mind and "habitation" (Portrait, p. 429), James reveals the reality that Osmond not only has the possession of her wealth but also Isabel's mind and liberty:

Her mind was to be his - attached to his own like a small garden-plot to a deer-park. He would rake the soil gently and water the flowers; he would weed the beds and gather an occasional nose-gay. It would be a pretty piece of property for a proprietor already farreaching. He didn't wish her to be stupid. On the contrary, it was because she was clever that she had pleased him. But he expected her intelligence to operate altogether in his favour. (Portrait, p. 432)

The relativity of such terms as "small garden-plot" and "deer-park," which Osmond emphasises are inseparable, is characteristic of Schopenhauer in his treatment of a woman's mind where he considers a woman as a liver without a gall-bladder and believes that she should constantly stick "to what is subjective." Even at the catastrophic moment in which Isabel informs Osmond that Ralph is ill and she wants to meet him before his death, Osmond reiterates that they are "indissolubly united" as husband and wife. He has an ideal of what his wife "should do and should not do," he tells her:

She should not travel across Europe alone, in defiance of my deepest desire, to sit at the bedside of other men. Your cousin's nothing to you; he's nothing to us. You smile most expressively when I talk about $u s$, but I assure you that we, we, Mrs. Osmond, is all I know. I take our marriage seriously; you appear to have found a way of not doing so. (Portrait, p. 536)

James reveals the true nature of matrimony through Osmond's character in this passage. Osmond's deliberate use of "Mrs. Osmond" states his belief of possession of Isabel, in every facet that one can be possessed. He self-consciously refers to Isabel as "Mrs. Osmond" during their verbal exchange, to demonstrate the loss of her former identity. James is remarkable in this instance of masculine superiority, as he boldly paints the strokes of the theme of possession in marriage. The novel shows Osmond's claim of authority over Isabel, by seemingly stripping away even the right for debate, or discussion with him, all the while, cloaking his desire for control with flowery wording such as Osmond stating he "takes [their] marriage seriously" and his concern of her travelling across Europe alone. James boldly exhibits that Isabel is either naive, or has no free will of her own. Based on this assertion of marital unity and masculine superiority, Osmond plays a role of superiority, and labels Isabel's idea of independency in marriage as superficial. It is to the full realisation of the two former passages and the idea of absolute authority in Osmond's character and absolute submission in Isabel's that the concept of possession can be expressed through Schopenhauer's philosophy where he remarks that women play an inferior role to men in the matter of consciousness because of their weak reasoning faculty.

These images of superiority and inferiority between Isabel and Osmond which characterise their relationship can also be approached through Schopenhauer's elucidation of the egoist's urge for domination: he

either destroys or injures this other body itself, or compels the powers of that other body to serve his will, instead of serving the will that appears in that other body. ... Moreover, wrong manifests itself in the subjugation of another individual, in forcing him into slavery. (World 1, p. 334-35)

This Schopenhauerian tenet appears in the novel when the narrator introduces Isabel as a person who wants others to treat her as a superior. Her refusal of Goodwood's and Warburton's proposals reveals Isabel's strong conviction that "she is the proprietor of herself" and "her decision to marry Osmond is [also] based on a desire to marry a man who will enable her to maintain this sense of self-proprietorship" (Flannery, 2000, p. 38). But later James demonstrates that such a thing is impossible. Towards the end of the novel, after Isabel confronts the misery that composes her marriage, she dutifully reminds herself that Osmond is her "appointed and inscribed master":

[S]he gazed at moments with a sort of incredulous blankness at this fact. It weighed upon her imagination, however; constantly present to her mind were all the traditional decencies and sanctities of marriage. The idea of violating them filled her with shame as well as with dread, for on giving herself away she had lost sight of his contingency in the perfect belief that her husband's intentions were as generous as her own. (Portrait, p. 462)

From the beginning Isabel is afraid of custody in marriage. The idea of any marriage, whether to Warburton or Goodwood, upsets Isabel, who looks at matrimony as possession. Goodwood "seemed to deprive her of the sense of 
freedom" (Portrait, p. 114). Warburton occupies a position that appeals to Isabel's imagination. "Great responsibilities, great opportunities, great consideration, great wealth, great power, a natural share in the public affairs of a great country" (Portrait, p. 71) but he negates Isabel's mind and knowledge. Isabel feels that he thinks that she is a "barbarian ... and that [she has] never seen forks and spoons" (Portrait, p. 70). That is the point that makes her disqualify him for she does not "need the aid of a clever man to teach [her] how to live" (Portrait, p. 158). Before marriage Osmond treated her "so completely as an independent person" (Portrait, p. 350) with a personal mind. Not long after marriage, she realises that she was deceived. Nevertheless, when in England Ralph asks her to stay instead of going back to Rome she says, "I should like to stay - as long as seems right" (Portrait, p. 577). Not surprisingly, she knows now the fact that she is in possession of her husband and he is the "master of the house" (Portrait, p. 370). James critically portrays the origin of freedom in relation with the other sex; and probably for the same reason his heroine does not see any freedom even in Goodwood's "act of possession" (Portrait, p. 591) by the end of the novel.

\section{Conclusion}

The heroine's final refusal resembles Schopenhauer's concept of negative and positive freedom. If Isabel by the end wills to return to her husband, it is because she knows that even in staying with Goodwood there is no independence. She has acknowledged that union without confinement and self-rejection is impossible, and the force behind liberty's image is nothing more than the destructive will. She knows that moving in line with the will for a personal and permanent freedom is a negative sort of freedom while ignoring oneself for another can result in the joyful and positive form of freedom. It is important for James what things are in their reality and how they are seen. James's main character strives for freedom and independence but she discovers that her idea of freedom can happen only through self-rejection and compassion for another on whom she must depend.

\section{References}

Buelens, G. (February 2005). Metaphor, Metonymy, and Ethics in The Portrait of a Lady. The Power of Perception: Aesthetics, Internationalism, and Visual Culture in Henry James.J. F. Kennedy Institute: Berlin. Access date: 10 Nov. $2013<\mathrm{http}: / /$ mockingbird.creighton.edu/english/Buelens.htm>

Edel, L., \& A., Tintner (1987). The Library of Henry James. Ann Arbor: UMI research press.

Firebaugh, J. (Dec. 1958). A Schopenhauerian Novel: James's The Princess Casamassima. Nineteenth-Century Fiction 13.3: pp. 177-197.

Flannery, D. (2000). Henry James: A Certain Illusion. Aldershot: Ashgate.

Grimwood, T. (Dec. 2008). The Limits of Misogyny: Schopenhauer, 'On Women.’ Kritike, 2(2), 131-145.

James, H. (1966; rpt. 1976). The Portrait of a Lady. England: Penguin.

Matthiessen, F. O. (1947). The James Family. New York: Knopf.

Schopenhauer, A. (2007). Metaphysics of Love. Essays of Schopenhauer. Trans., R. Dircks. Boston: Indy Publish.

Schopenhauer, A. (2007). “On Women.” Essays of Schopenhauer. Trans. Rudolf Dircks. Boston: Indy Publisher.

Schopenhauer, A. (1966). The World as Will and Representation. Trans. E F J. Payne. 2 Vols. New York: Dover.

Wegelin, C. (1958). The Image of Europe in Henry James. Dallas: Southern Methodist University Press.

\section{Notes}

Note 1. See The Library of Henry James

Note 2. For further details see J. Firebaugh's article on “A Schopenhauerian Novel: James's The Princess

Casamassima"

Note 3. Based on her previous experience of marriage, she knows that personal freedom in conjugal life is impossible. Therefore, accepting Goodwood's offer is another imprisonment.

Note 4. This in no way means that James also had the same feeling, reflecting his views.

Note 5. From the 1930's and thereafter, Schopenhauer's total despisement of women has gone relatively unchallenged in philosophical literature. Biographers of Schopenhauer have recognised and criticised his misogynistic character, so my study uncover no new biographical data.

Note 6. "This is most striking in regard to painting, the technique of which is as much within their reach as within ours; this is why they pursue it so industriously. Still, they have not a single great painting to show, for the simple reason that they lack that objectivity of mind." P.47 